University of Wollongong

Research Online

Faculty of Arts, Social Sciences and Humanities

- Papers

Faculty of Arts, Social Sciences \& Humanities

2020

Middle leading in Australian schools: professional standards, positions, and professional development

Kylie Lipscombe

University of Wollongong, klipscom@uow.edu.au

Christine Grice

Sharon K. Tindall-Ford

University of Wollongong, sharontf@uow.edu.au

John J. De Nobile

john.denobile@mq.edu.au

Follow this and additional works at: https://ro.uow.edu.au/asshpapers

Research Online is the open access institutional repository for the University of Wollongong. For further information contact the UOW Library: research-pubs@uow.edu.au 


\title{
Middle leading in Australian schools: professional standards, positions, and professional development
}

\author{
Abstract \\ In Australia, there is a national education agenda for school improvement with an increasing focus on \\ how school leaders can fulfil this agenda. As school principals are arguably faced with increasing \\ demands, the importance of school middle leaders is increasing. This article presents the initial findings \\ from a larger project on middle leadership in Australian schools, the first phase of which is a documentary \\ analysis of significant texts including policy documents, websites and reports. The purpose of the \\ document analysis was to examine expectations placed on, and support provided for, school middle \\ leaders in Australian schools to make explicit the potential implications for policymakers, leaders and \\ researchers investigating this field. We argue there is a lack of clarity about the role of middle leadership \\ across Australia, with unclear policies, and variations in expectations, titles and levels of support. What is \\ evident is that middle leaders play a pivotal role as they lead teaching, learning, and pastoral care. They \\ carry out these roles in subject areas, key stages and classrooms, and among teachers. While there are a \\ range of professional development provisions for middle leaders across different states, middle \\ leadership needs to be an area of increased focus across Australia.
}

\section{Keywords}

positions, development, leading, standards, middle, professional, schools:, australian

\section{Publication Details}

Lipscombe, K., Grice, C., Tindall-Ford, S. \& De-Nobile, J. (2020). Middle leading in Australian schools: professional standards, positions, and professional development. School Leadership and Management, Online First 


\section{Middle Leading in Australian Schools: Professional Standards, Positions, and Professional Learning}

Dr Kylie Lipscombe, Dr Christine Grice, Associate Professor Sharon Tindall-Ford \& Dr John De Nobile

Kylie Lipscombe

School of Education

University of Wollongong

Wollongong, Australia, 2533

Email: klipscom@uow.edu.au

ORCID: 0000-0001-9433-7971

Sharon Tindall-Ford

School of Education

University of Wollongong

Wollongong, Australia, 2533

Email: sharontd@uow.edu.au

0000-0002-1451-020X
Christine Grice

School of Education and Social Work

The University of Sydney

Sydney, Australia, 2006

Email: christine.grice@sydney.edu.au

0000-0002-7293-1926

John De Nobile

Department of Educational Studies

Macquarie University

Macquarie Park, Australian, 2109

Email: john.denobile@mq.edu.au

/0000-0002-5640-611X 
Middle Leading in Australian Schools: Professional Standards, Positions, and Professional Learning

\begin{abstract}
In Australia there is a national education agenda for school improvement with an increasing focus on how school leaders can fulfil this agenda. As school principals are arguably faced with increasing demands, the importance of school middle leaders is increasing. This article presents the initial findings from a larger project on middle leadership in Australian schools, the first phase of which is a documentary analysis of significant texts including policy documents, websites and reports. The purpose of the document analysis was to examine expectations placed on, and support provided for, school middle leaders in Australian schools to make explicit the potential implications for policy makers, leaders and researchers investigating this field. We argue there is a lack of clarity about the role of middle leadership across Australia, with unclear policies, and variations in expectations, titles and levels of support. What is evident is that middle leaders play a pivotal role as they lead teaching, learning, and pastoral care. They carry out these roles in subject areas, key stages and classrooms, and among teachers. While there are a range of professional development provisions for middle leaders across different states, middle leadership needs to be an area of increased focus across Australia.
\end{abstract}

Keywords: Middle leadership, professional development, school leadership, professional teaching standards

\title{
Introduction
}

It is well established that school leaders make a significant difference in education (Leithwood et al. 2006; Robinson, Hohepa and Lloyd 2009) and have the potential to improve the educational outcomes of students in Australian schools (Mulford and Silins 2003). While past research and 
scholarship has primarily focussed on understanding the leadership provided by principals (Leithwood et al. 2006; Wilkinson and Kemmis 2015), interest in and acknowledgment of the practices and contributions of middle leaders in schools is increasing in research, policy and professional development opportunities (Harris and Jones 2017). This is due to considerations such as the increased demands placed on principals (NSW Department of Education 2017) and the expertise of middle leaders who are often promoted to formal leadership positions as a result of their effective teaching practices (Grootenboer 2018). As they combine the roles of classroom teachers and school leaders, middle leaders are well placed to make direct and positive impacts on teacher and student learning at the primary site of a school, the classroom (Grootenboer 2018).

In almost all educational institutions there are those who have middle leadership roles, with their educational leadership being unique and critical to leading and enacting teaching and learning innovations in their schools (Leithwood 2016). As a result of the contextual nature of the role, defining middle leadership is no simple task. Forde et al. (2019), in a study focussed on Scottish and Irish education, defined middle leadership as involving 'teaching alongside "out-ofclassroom" responsibilities' (299). Similarly, Glover (1998) suggests that middle leaders are not only classroom teachers but are highly accomplished or leading teachers who have additional responsibilities. These extra obligations are often a result of formal posts or positions such as heads of subjects and year coordinators (Irvine and Brundrett 2016; Grootenboer 2018). Having said this, it must also be recognised that middle leadership can occur outside of formal promotion positions (Boylan 2018; Fairman and Mackenzie 2015; Youngs 2014). Some examples of this include teachers who take on responsibility for a subject area without a formal head-of-subject designation, and teachers who organise events in the school or lead minor innovations in practice (Boylan 
2018). Davies (2009) argues that the distinct nature of schools means that boundaries are often porous, and that defining and delineating middle leadership from other roles is often difficult. This seems apparent in both the practicalities of roles in schools and the research literature. For example, the informal leadership activities listed above, in relation to informal roles, were taken from studies of teacher leadership. While we are not asserting that teacher leadership and middle leadership are necessarily the same thing, it is apparent that teacher leaders are involved in leadership activities that have significant impacts on teacher practice and school organisation (Boylan 2018; Cosenza 2015; Fairman and Mackenzie 2015; Lumby 2019; Muijs and Harris 2007). As such, some researchers (e.g., Grootenboer 2018; Edwards-Groves et al. 2019) have moved away from a focus on middle leadership as a distinct role and instead are focussing on middle leading as practice, describing the work middle leaders do in context rather than attempting to define their roles. Day and Grice (2019) explain that middle leading is dependent upon interactions with others, and as such the role cannot be analysed or defined in isolation from its context, or in isolation from the leaders who support and co-define middle leading practices.

Middle leadership could be described as an emergent concept in the literature on educational leadership. However, in Australia the evolution of middle leadership in schools has occurred over several decades. The formal middle leadership positions that exist in Australian schools today reflect this evolution as well as the influences of the jurisdictional (state and territorial) and sectoral (government and non-government) contexts in which they are located. Whilst the current leadership structures are necessary and helpful for the running of schools, the influences mentioned above have resulted in a confusing array of terms to describe the formal positions of middle leaders across Australia. This has no doubt contributed to the confusion that exists around what middle 
leadership is and who middle leaders are in schools. For example, in New South Wales, 'assistant principal' in government primary schools is a middle level leadership position typically involving both teaching and formal leadership responsibilities, while in most Catholic schools the assistant principal is the equivalent of the NSW government school deputy principal (New South Wales Department of Education 2018; Sydney Catholic Schools and NSWIEU 2018) who is more formally referred to as a senior leader with no or limited teaching responsibilities, but whole school leadership responsibilities. Commonly across Australia, middle leaders hold positions such as heads of curriculum, and they lead teams of teachers in specific areas or projects. Primary and secondary school middle leaders may perform different functions, and they may have different responsibilities and areas of influence within their schools. In addition, middle leaders in government and non-government sectors may have different aspects of their roles emphasised, based upon the historic and traditional purposes of middle leaders within their contexts. In some jurisdictions middle leaders also perform roles as coaches and specialists. Instead of performing the dual roles of classroom teacher and leader, they lead teacher development and professional development without classroom teaching responsibilities. Consequently, across Australia, middle leadership is diverse and disparate. Middle leaders can be teachers who have formal or informal leadership roles, and they may or may not have classroom teaching responsibilities. They are commonly responsible for leading a team of people, a project or a curriculum area. Regardless of terms, what is common in the literature and in practice is that middle leadership is not the same as principal leadership (Wilkinson 2017; Wilkinson and Kemmis 2015) and instead involves interactions between executive school leaders and teachers. It is commonly referred to as 'leading from the middle' (Hargreaves et al 2018). 
The relationship 'in the middle' is often referred to in the literature as leadership distribution where leadership responsibilities are distributed, most often by the principal, among schoolteachers (Grice 2019; Lárusdóttir and O’Connor 2017; Spillane 2006) creating school middle leaders. This is often seen as the result of the increasing administrative and leadership expectations placed on senior leadership in schools (Dinham 2016; Marks and McCulla 2016; McGrath-Champ et al. 2018; Riley 2014; Weldon and Ingvarson 2016). While the distribution of responsibilities and the autonomy that middle leaders have varies (Fullan 1993), what is understood is that middle leadership is a relational act where middle leaders work between school leaders and teachers (Grootenboer 2018), building trust with colleagues and moving between administration and pedagogy (Edwards-groves, Grootenboer and Ronnerman 2016; Grice 2018). While this distributed 'in the middle' role has certain affordances for middle leaders, such as empathy with teachers as colleagues and an understanding of the school site from within, it also comes with many identified challenges. To meet these challenges, middle leaders require certain conditions. De Nobile (2017) identified six core conditions for middle leader success: principal support, professional development, culture, enthusiasm, drive and knowledge. Similarly, Lipscombe, Tindall-Ford and Grootenboer (2019), suggest resourcing, clear role expectations and trusting relationships are crucial to facilitating middle leaders' work.

This article presents the initial findings from a larger project on middle leadership in Australian schools, the first phase of which is a documentary analysis of middle leadership which examines the expectations of, and support for, Australian school middle leaders. To explore these areas, three central questions are posed: How are middle leaders defined in Australian schools? What are the responsibilities of middle leaders in Australian schools? and What opportunities are available for 
professional development in middle leadership? We acknowledge the terms professional development and professional learning are often used synonymously in policy, literature and research. For the purposes of clarity, we use the term professional development in this paper to refer to activities and experiences that may lead to teacher learning.

\section{Methodological Approach to Document Analysis}

The key findings presented in this paper are primarily drawn from an analysis of public records pertaining to middle leadership in Australian schools. Document analysis has been described as a useful method to interrogate culture through written expression (Hodder 2000). It provides researchers with information that can help them to understand the insights, assumptions and motivations presented in documents and meaning of the phenomena under investigation (Perryman 2012; Young and Dien 2017).

Documentary research requires researchers to select and analyse data as a means of interpreting and explaining what has occurred (Fitzgerald 2012) and it requires them to place the data in major themes or categories (Labuschagne 2003). Providing a complete analysis of middle leadership in Australia is an impossible task because of the influences of different contexts including different state-level jurisdictions as well as diverse school sectors (e.g. public, catholic and independent). Bowen $(2009,33)$ suggests therefore selecting a wide array of documents to provide a 'preponderance of evidence' that align to the purpose of the study instead of focussing on how many documents to analyse.

Documents were selected in this study to include national, state and organisational-level documents that were publicly attainable and associated with middle leadership in Australian 
schools. The documents analysed (Table 1) included national professional teacher and leadership standards, school sector employment agreements, and school and state-wide professional development institute websites. Other documents, including research literature, were consulted but were not foregrounded in the analysis and instead were more descriptive of the environment and research context. Collectively, these documents detail the professional standards, levels of responsibility and duties and professional development opportunities currently in place for middle leaders across Australia.

Table 1: Documents and data analysed

\begin{tabular}{|l|l|}
\hline $\begin{array}{l}\text { Documents selected } \\
\text { Australian Professional Standards for Teachers-Highly Accomplished (AITSL, } \\
\text { 2011) }\end{array}$ & Professional standards for leaders \\
\hline Australian Professional Standards for Teachers - Lead (AITSL, 2011) & Professional standards for leaders \\
\hline Australian Professional Standard for Principals (AITSL, 2014) & Professional standards for leaders \\
\hline $\begin{array}{l}\text { Framework for Workplace Practices in Primary Schools (Sydney Catholic } \\
\text { Schools \& IEU, 2018). }\end{array}$ & $\begin{array}{l}\text { Middle leadership positions and } \\
\text { responsibilities }\end{array}$ \\
\hline $\begin{array}{l}\text { NSW and ACT Catholic Schools Enterprise Agreement2017 (Fair Work } \\
\text { Commission Australia,2018) }\end{array}$ & $\begin{array}{l}\text { Middle leadership positions and } \\
\text { responsibilities }\end{array}$ \\
\hline Role description policies (Queensland Department of Education, 2019) & $\begin{array}{l}\text { Middle leadership positions and } \\
\text { responsibilities }\end{array}$ \\
\hline $\begin{array}{l}\text { Leadership Institute website (Western Australian Department of Education, } \\
\text { 2019) }\end{array}$ & $\begin{array}{l}\text { Middle leadership positions and } \\
\text { responsibilities }\end{array}$ \\
\hline Roles and Responsibilities Agreement (Victoria Education and Training, 2017) & $\begin{array}{l}\text { Middle leadership positions and } \\
\text { responsibilities }\end{array}$ \\
\hline $\begin{array}{l}\text { Western Australia Department of Education website (WA Department of } \\
\text { Education, 2019) }\end{array}$ & $\begin{array}{l}\text { Middle leadership professional development } \\
\text { opportunities }\end{array}$ \\
\hline NSW Association of Independent Schools website (AISNSW, 2019) & $\begin{array}{l}\text { Middle leadership professional development } \\
\text { opportunities }\end{array}$ \\
\hline
\end{tabular}


Queensland Educational Leadership Institute website (QELi, 2019)

Victoria BASTOW Institute of Educational Leadership website (BASTOW, 2019)

Nesli Catholic Schools' Middle Leadership Programme (Nesli, 2019)
Middle leadership professional development opportunities

Middle leadership professional development opportunities

Middle leadership professional development opportunities

Documents were analysed by the researchers, who not only looked for factual information but also aimed to obtain an interpretative understanding (Scott 1990) in order to identify underpinning assumptions about middle leadership. Thematic analysis, which recognises patterns in documents and organises them into categories for analysis (Bowen 2009) was firstly utilised. The researchers engaged in concentrated looking, suggested by Diem and Young (2015) as an essential approach to developing the deep understanding required in document inquiries. This approach allows researchers to question what is happening in documents and to assess more critically viewpoints that are present. To undertake this analysis, firstly, each document was read individually by the four researchers in its entirety to obtain a holistic impression of its meaning. Next, the researchers discussed their analysis and together began the initial coding of data using line-by-line coding based on three groups of search terms associated with the following research areas: (1) definitions of middle leadership; (2) responsibilities of middle leaders; and (3) professional development opportunities for middle leaders. Based on the coding, broad themes were derived from each text. These themes were then applied across all texts to reduce the number of codes. These themes formed the conceptual framing for reporting the findings in the next section.

\section{Findings}


Through our documentary analysis of school middle leadership, we found that in Australia, middle leading is contextually bound by jurisdiction (state and territorial), sector (government and nongovernment) and school type (primary or secondary). This results in a multitude of terms and responsibilities. Whatever the terminology, middle leadership work in Australia is multifaceted (Leithwood 2016), and it typically involves classroom teaching in conjunction with 'out of classroom' work ranging from school management tasks to leading school improvement initiatives. In this section we report on the codes of meaning obtained from the analysis of documents in conjunction with research literature to examine the expectations of, and support for, school middle leaders in Australian schools.

\section{Professional standards and middle leaders: a complex and ambiguous policy landscape}

The development of national policy standards for school leadership in Australia reflects an international trend: to describe, promote and clarify the work of leaders through sets of standards and requirements. In this way, standards as policy documents aim to create consistency, classify and organise people and ideas, and communicate expectations (Fransson and McMahan 2013; Shore and Wright 2011) to ultimately inform practice. Our document analysis revealed that for middle leaders in Australian schools, the current school leadership policy landscape is a complex one in which there is no single set of guidelines which applies to all middle leaders. Instead, according to the Australian Institute of Teaching and School Leadership (AITSL 2011), leadership requirements that are relevant to teachers in leadership roles such as middle leaders are detailed in three national policy documents: the Australian Professional Standards for Teachers (APST) (AITSL 2014) at the Highly Accomplished (HA) and Lead Teacher (LT) stages and the Australian Professional Standard for Principals (APSP). Notably, the discrete nature of these policies means 
that they provide disparate views on guidelines for middle leaders. The HA and LT Standards deal with two of four career stages that make up the professional standards for teachers in Australian schools and are primarily focussed on using expertise in classroom teaching to develop the practices of others (e.g. colleagues).

The HA career stage follows the graduate and proficient career stages of the teacher standards. According to AITSL (2011), highly accomplished teachers have expertise in data-informed teaching and learning practices and keep abreast of educational development in their content areas. As well as being regarded as effective teachers, they are expected to contribute to their colleagues' professional development by advising, supporting and working alongside them to improve teacher practice and student achievement. Similar to HA teachers, LT are exemplary teachers who are expected to contribute to both the internal and external activities of the schools. Internally, they are skilled at developing colleagues' practices through, for example, mentoring. They lead change through innovation, inspiration and evaluation of school and teaching practices that lead to improved educational development. They represent the school and the teaching profession in the local community and beyond. Notably, LTs appear to have more authority at the organisational level than HA teachers. Both HA and LT career stages emphasise the dual roles of teaching and staff development. As staff developers, they are responsible for developing their colleagues' professional practices.

Importantly, HA and LT are the only two career stages where teachers can voluntarily seek certification for their practice through a rigorous process of evidence, reflection and feedback. Interestingly, the certification process explained by AITSL (2017) is aimed at promoting quality 
teaching, not specifically leadership, thus illustrating one of the challenges we elaborate on further in this section surrounding a lack of leadership focus for Australian school middle leaders.

Interestingly, The Australian Professional Standard for Principals (APSP) has been suggested by the Australian Institute for Teaching and School Leadership (AITSL 2014) as a useful framework for middle leaders. This is illustrated in a short video clip on the AITSL website that explains that the APSP is useful for developing both the current and emerging capabilities of teachers who are also leaders in schools. The video states that teachers who lead a team, manage a budget, coach colleagues and help coordinate professional learning 'can look to APSP to inform their current work, with the policy providing direction for school leaders to develop their leadership skills and practices'. The APSP describes the leadership requirements and professional practices a principal should know, understand and apply to be a successful school leader (AITSL 2014). There are three leadership requirements (vision and values; knowledge and understanding; and personal qualities and social and interpersonal skills) and five professional practices (leading teaching and learning; developing self and others; leading improvement, innovation and change; leading the management of the school; engaging and working with the community) that are addressed by the policy. While the APSP discourse is replete with responsibilities associated with the role of principal, there is a somewhat limited acknowledgment that the standard is of significance for leadership roles other than that of principal.

While some may argue that the HA and LT standards support middle leaders to lead in their current practice, and while the APSP helps develop their aspirations for future leadership, the standards are very disparate, and we argue they offer limited clear pathways for middle leaders. This lack of consistency in policy documents, we believe, is what some researchers have suggested is the 
difficulty with standards, in that they fail to adequately describe the requirements and competencies of teachers and leaders, as education is replete with diverse contexts, and as such standards should provide flexibility according to factors such as environment, resources and experience (Bourke et al. 2013; Connell 2009; Eaude 2014). While the HA and LT Standards are focussed on the adaptive and collaborative qualities of experienced teachers, the APSP is focussed on the role of the principal. As such, present policy documents may provide an inadequate guide for middle leaders to gain clarity on what is expected of them and these documents may also be of limited use for informing their practice.

\section{Disparate leadership positions and responsibilities across states and sectors}

The national professional standards discussed above 'provide national leadership for the Commonwealth, state and territory governments in promoting excellence in the profession of teaching and school leadership' (AITSL 2018). However, it is important to note that each state and territory in Australia has its own variations on the leadership expectations and structures and as a result sets out its own expectations for middle leader positions and responsibilities. While the Standards may aim to develop greater consistency between state and territory school systems, our document analysis revealed that middle leader positions and responsibilities are vary widely in different states and school sectors. Providing a comprehensive analysis of all positions and responsibilities of middle leaders across Australia is a difficult task because of the influence of different states and school sectors. As such, we selected and analysed four examples of employment-related documents across four states in Australia: New South Wales, Queensland, Western Australia and Victoria. Secondary documents from the research literature were used to support an understanding of context and historical orientations. 
An analysis of middle leadership in NSW Catholic education indicated that since the 1990s, middle leadership roles and responsibilities have been aligned to a three-tiered coordinator framework. The development of this tiered model was partly due to industrial pressure to establish better career paths for teachers as well as rationalise leadership roles so that workloads were more manageable (De Nobile and Boffa 2014). Notably, in the NSW and ACT Catholic Systemic Schools Enterprise Agreement 2017, Coordinator 1 teachers are responsible for areas such as curriculum and program development, while Coordinator 3 teachers are responsible for major school initiatives such as supervision of staff curriculum evaluation. Coordinator 3 teachers therefore have more responsibility in areas such as performance and management (Fair Work Commission Australia 2018).

The role of assistant principal in New South Wales government schools is a little more complicated to explain than the roles of coordinators in Catholic schools. In NSW government schools there appears to be a middle leadership echelon below the principal and deputy principal. Principals and deputy principals are predominantly focussed on organisational or whole school leadership, with few if any teaching responsibilities, while middle leaders, typically known as assistant principals in primary schools occupy a formal leadership position in addition to their teaching responsibilities. Assistant principals in primary schools (and central schools consisting of Kindergarten to Year 10) in NSW government schools have responsibilities similar to head teachers (e.g., English Head Teacher) in secondary schools (Lambert, Marks, Elliott and JohnstonAnderson 2016).

In Victorian government schools, assistant principals in primary and secondary schools are often referred to as executive or senior leaders instead of middle leaders. This is because typically they 
are primarily responsible for managing significant areas and functions of the organisation (Victoria Department of Education and Training 2017) with few if any teaching responsibilities. Instead, Leading Teachers and Learning Specialists are the formal middle leaders. A lead teacher's primary role is to improve the skills, knowledge and performance of teachers. Lead Teachers have a high degree of independence to directly impact and influence the achievement of school goals. They are responsible for areas such as whole school curriculum development, policy development and implementation, leading and managing school priorities and staff performance and development. In comparison, Learning Specialists are highly skilled teachers who spend most of their time in the classroom but have additional responsibilities including teaching demonstrations and observations as well as facilitating school-based professional learning. It is important to note that unlike Lead Teachers, they are not typically responsible for staff performance and management.

Our document analysis of school leadership structures in other Australian states suggests that middle leaders have become more prominent in schools. In the state of Queensland, for example, there has recently been an increased recognition of the role middle leaders play. Queensland government schools have senior teachers and heads of curriculum in their school leadership structures, and more recently they have introduced classroom coaches who specialise in pedagogy, literacy and early years education (Queensland Department of Education 2019). The Catholic Education Office of Brisbane now lists curriculum leaders, program leaders and pastoral leaders as formal middle leadership positions in their secondary schools (Brisbane Catholic Education 2019). In the Western Australian Department of Education (2019), coordinators, senior teachers, heads of learning areas, program leaders and Level 3 classroom teachers are classified as middle leaders who have teacher leadership roles in primary and secondary schools. In both states, the responsibilities of middle leaders include supporting the school executive; enhancing learning and teaching; supporting teachers; developing, implementing and evaluating curriculums; and driving new initiatives. 


\section{Professional development opportunities for middle leaders}

Five middle leadership programs in Australia were analysed to represent the different states and school jurisdictions. It is important to note that some of the professional development providers examined here offer additional professional development opportunities that are associated with middle leadership such as instructional leadership and coaching; however, for the purposes of this document analysis, only programs solely focussed on middle leaders were considered. Middle leadership professional development programs varied in duration from two days to 12 months. Program structures included face-to-face (F2F) and online workshops, mentoring/shadowing, leadership projects and professional readings. An overview of each program is provided in Table

\section{2.}

Table 2: Middle leadership professional development program overview

\begin{tabular}{|c|c|c|c|}
\hline Programme & Duration & Structure & Targeted audience \\
\hline $\begin{array}{l}\text { Western } \\
\text { Australia Middle } \\
\text { Leaders: Leading } \\
\text { from Within }\end{array}$ & $\begin{array}{l}\text { Two-day } \\
\text { programme }\end{array}$ & Two F2F workshops & $\begin{array}{l}\text { Aspirantschoolleaderormiddle } \\
\text { manager }\end{array}$ \\
\hline $\begin{array}{l}\text { NSW AIS } \\
\text { Leading From the } \\
\text { Middle }\end{array}$ & 12 months & $\begin{array}{l}\text { Five F2F workshops } \\
\text { Pre-readings } \\
\text { School based project } \\
\text { Poster presentations }\end{array}$ & Middle leadership teams \\
\hline $\begin{array}{l}\text { Nesli Catholic } \\
\text { School Middle } \\
\text { Leadership } \\
\text { Programme }\end{array}$ & 6 months & $\begin{array}{l}360 \text { degree Leadership Effectiveness and } \\
\text { aptitude profile } \\
\text { Three F2F workshops } \\
\text { Online Modules } \\
\text { Coaching } \\
\text { Personal leadership project } \\
\text { Interactive online portal }\end{array}$ & $\begin{array}{l}\text { Teachers in Positions of Added } \\
\text { Responsibility or exercising leadership } \\
\text { in other capacities. }\end{array}$ \\
\hline
\end{tabular}




\begin{tabular}{|l|l|l|l|}
\hline $\begin{array}{l}\text { QELi Leadership } \\
\text { for Middle } \\
\text { Leaders } \\
\text { Programme }\end{array}$ & 9 months & $\begin{array}{l}\text { Three F2F workshops } \\
\text { Action Research } \\
\text { Project } \\
\text { Coaching }\end{array}$ & Middle leaders in all schooling sectors \\
\hline $\begin{array}{l}\text { Bastow CREATE: } \\
\text { Middle Leaders }\end{array}$ & 12 months & $\begin{array}{l}\text { EightF2F workshops Leadership shadowing } \\
\text { (optional) } \\
\text { Online community collaboration } \\
\text { Leadership project in school } \\
\text { Principal mentoring }\end{array}$ & $\begin{array}{l}\text { Middle leaders in formal and informal } \\
\text { roles } \\
\text { Principals also need to make } \\
\text { specific contributions throughout the } \\
\text { programme. }\end{array}$ \\
\hline
\end{tabular}

Importantly, the document analysis led to several findings. Firstly, professional development programs typically focus on collaboration, change and influence, but more complex areas such as leading in conflict situations and supporting underperforming colleagues are less obvious. Secondly, a focus on middle leadership development through school site projects appeared to be an important aspect of professional development. Professional development program partnerships were common but varied, serving different purposes for different types of organisations. Finally, the target audience of the middle leadership program revealed that middle leadership professional development is typically targeted towards formal leadership positions with limited opportunities for aspiring or informal middle leaders.

The quality of an educational leadership program is determined, to an extent, by what is learned. From the documents analysed, middle leadership professional development typically focusses on the areas of: understanding self-leadership, leading teacher dialogue and reflection, leading change and influencing others, collaboration and relationships and trust. For example, the notion of self development was illustrated in the NSW AIS (2019) Leading From the Middle by a focus developing a leadership philosophy and understanding of self as leader. Similarly, the Bastow 
(2019) CREATE: Middle Leaders and the QeLi (2019) Leadership for Middle Leaders Programs also include a focus on the self-development of leaders. The leadership of teams through dialogue, reflection and data was also identified as a common professional development focus. Examples such as collaborative leadership, being open to learning conversations, engaging in reflective learning conversations, giving and receiving feedback, relationships and trust illustrate the focus on supporting middle leaders to work with others with a focus on improving teaching and learning. The complexity of leading change and influence was specifically acknowledged in four programs with topics such as change, influence and inspiring others. A less common focus area was resource management. Only one program explicitly identified an understanding of managing resources as a key outcome. Interestingly, there was little evidence of material related to leading and managing difficult staff behaviours. While focus areas such as 'high performance teams', 'persuasion' 'building capabilities' and 'managing people differently' were evident, only one program specifically identified material related to the complex, difficult and typical task for middle leaders managing colleagues who are underperforming or who are in conflict with one another.

A second theme from the document analysis of professional development programs was the inclusion of site-based learning such as action research projects where middle leaders drew upon knowledge learned within the professional learning program and applied it to their own schools. It may be posited that the purpose of site-based projects is to provide contextually focussed, meaningful learning and leading experiences that are beneficial to middle leaders and their schools. Given that middle leaders directly impact upon the quality of teacher learning and development (Edwards-Groves, Grootenboer, Hardy and Ronnerman 2019) and indirectly on classroom teaching and learning (Day 2017) and student outcomes (Day, Gu and Sammons 2016), their roles 
in developing their leadership on-site through the improvement of practice seems important. Sitebased learning opportunities align with the key andragogy principles of learning experientially, through problem solving and undertaking task(s) that are relevant and meet learner needs (Smith 2002). It may be argued that in order to increase the authenticity of middle leader professional development, professional development programs should also include the team that middle leaders work with. This 'team approach' to middle leaders is evident within programs offered by NSW AIS (2019) and QELi (2019).

Partnerships across multiple organisations which deliver middle leadership professional development were evident in three of the five programs. From the document analysis it appeared that different partnerships served different purposes. For example, in the case of the Bastow (2019) CREATE program, the partnership is with two universities. While the partnership arrangements were not entirely clear, an explanation of one purpose is available on the BASTOW (2019) website which states the two universities 'offer free subject credits or discounted Professional Practice credentials for a range of Bastow professional learning, including Create: Middle Leaders' (Bastow 2019). In contrast, the Western Australian Department of Education (2019) middle leading program is partnered with a private multinational company where presenters from the organisation facilitate learning for middle leaders. The Nesli Catholic Schools Middle Leadership program (2019) was co-developed by NESLI (the National Excellence in School Leadership Initiative), a provider of online leadership professional development programs and Catholic Education South Australia. This partnership between a school sector organisation and a private company aimed to ensure a contextualised leadership program that 'finds deep connection with our Catholic context, our leaders and our unique system of schools' (NESLI 2019). 
A final theme identified through the document analysis was related to audience. Four of the five programs were specifically targeted towards educators who currently held middle leadership positions. One program was specifically targeted towards teams of middle leaders. Additionally, one program specifically requested that principals of middle leaders must contribute to the program. Only one program included those aspiring towards middle leadership as well as those who were current middle leaders.

\section{IMPLICATIONS AND CONCLUSIONS}

The middle leadership document analysis described in this study suggests there is an increasing interest in and acknowledgement of the importance of school middle leadership in Australia. Reasons include: the increasing complexity of schools (De Nobile 2017; Harris and Jones 2017); an increase in the amount of administrative work leaders are required to do (Dinham 2016; Marks and McCulla 2016); and government policies focussed on school improvement initiatives (Lipscombe, Tindall-Ford and Kirk 2019) with middle leaders increasingly viewed as instrumental in enacting these initiatives through improving school learning and teaching practices (Leithwood 2016). The following discussion answers the three research questions that were the focus of this document analysis: How are middle leaders defined in Australian schools? What are their responsibilities? and What professional development opportunities are afforded to them?

What is evident from the document analysis is that focussing on the terminology used to refer to Australian middle leadership is counter-productive to researching and understanding the middle leadership space. Our analysis of four policy documents revealed a plethora of different terms, including assistant principal, learning specialist, classroom coaches and others. We argue that the 
combination of classroom teaching with some form of school leadership position (e.g. director of teaching and learning, curriculum coordinator, subject or year coordinator, head of the department, student well-being coordinator) is the feature that middle teacher-leaders have in common. As middle leaders' titles, as well as the expectations placed on them and the roles they perform, are dependent on their school contexts, we like other researchers (e.g. Grootenboer, 2018), argue that focussing on their practices rather than their titles is the most effective approach for school leaders, researchers and policy makers to adopt in order understand and support middle leaders' work. This would be particularly beneficial to research across countries as the role titles and responsibilities of middle leaders increases in diversity.

This leads to the important issue identified by this study: the lack of clear references of middle leading in Australian teaching and leading policy documents. Indirect references to middle leaders' practices can be found in two policy documents, the Australian Professional Standards for Teachers (APST) at Highly Accomplished (HA) and Lead Teacher (LT) Levels and the Australian Professional Standards for Principals (APSP). The first document focusses on HA and LT teachers as teachers who are responsible for developing the skills of teacher colleagues - a responsibility that is central to middle leaders' work. However, the APST policy fails to acknowledge the significance of management and leadership as a part of HA or LT practices, and it does not mention the important relational contribution of middle leaders working between the school executive, teacher colleagues and students (Grootenboer, Edwards-Groves and Rönnerman 2015). In contrast, the second national policy, the APSP, focuses solely on whole school leadership, not the work of middle leaders. However, many of the leadership requirements within the personal and practice domains in the APSP are transferable and important to middle leading work. This lack of clarity and explicitness within the Australian middle leader policy landscape serves to compound 
the already unclear expectations placed on middle leaders in regard to their roles, expectations and authority. Research has shown that many middle leaders suffer from a lack of role descriptions, which leads to difficulties in fulfilling those roles (Leithwood 2016; Drysdale, Gurr and Goode 2016). Clear policies could help middle leaders to navigate their responsibilities and meet the expectations of principals and colleagues. This is particularly important given research that suggests middle leaders face significant challenges in influencing others due to a lack of clear responsibilities and authority (Gurr and Drysdale 2013; Hammersley-Fletcher and Strain 2011; Leithwood, 2016; Lipscombe, Tindall-Ford and Grootenboer 2019). These problems reduce the effectiveness and job satisfaction of middle leaders (Mayer and Zepeda 2002). As Grootenboer (2018) suggests, a detailed description of middle leaders' duties may be best done at the local site, but we suggest that the provision of an overarching policy would support consistency of understanding and communication of expectations (Fransson and McMahon 2013). Under these conditions, middle leaders could refer to a national policy to ensure that the expectations placed on them are consistent, manageable, realistic and fair within their own contexts. This is particularly important given the intensification of middle leaders' responsibilities and workloads at the school level (Fitzgerald 2009). The findings from this analysis provide evidence that without a national policy which acknowledges important middle leading practices, there will be no consistent national approach for the development of middle leaders' leadership capabilities. This document analysis, and the limitations it has identified in Australian policies may serve as important insights for other countries conceptualising and establishing policy associated with middle leadership.

Middle leading is a unique practice and working and leading from the middle of a school hierarchy is central to middle leaders' work. Therefore, there is a need to form sustained, trustworthy, 
collegial relationships with school executive, teacher colleagues and early career teachers (Grootenboer 2018). The flexibility, discipline and social and emotional capabilities required for such a position within a school are not well captured in either the APST or the APSP, or within current professional development offerings. We argue this has led to a lack of understanding and acknowledgment of the challenges implicit in middle leading, resulting in a lack of professional development for middle leaders' social and emotional capabilities. These qualities are central to managing, leading and inspiring colleagues.

Middle leading is becoming increasingly important within the Australian school reform agenda. Moreover, empirical evidence suggests that teachers leading 'in the middle' have a direct impact upon the quality of teacher learning and development (Edwards-Groves, Grootenboer, Hardy and Ronnerman 2019) and an indirect impact on classroom teaching and learning (Day, 2017) and student outcomes (Day, Gu and Sammons 2016). Therefore, we argue there is an imperative to understand middle leaders' policy, practice and professional learning to ensure the architectures surrounding middle leadership are supportive to lead effectively.

The document analysis undertaken within this paper informs this space both nationally and internationally. In Australian schools, there is a reform agenda in which middle leaders are seen as pedagogical leaders central to improving teacher practices and student learning. However, drawing on current national policy, teacher leadership frameworks may be counter-productive, as they fail to adequately inform middle leading professional learning. Empirical research which uses a range of research methodologies and data sources to understand middle leading practices and the conditions that may support or inhibit middle leading work may better inform targeted middle leading professional learning. This research could also speak to national policy, where middle leaders are currently not well represented. Understanding current middle leader policies, roles, responsibilities and professional learning in Australia could provide foundational understandings 
to inform the development of a theory of middle leading practices that may be a useful base for increasing research and developing greater understandings of this important leadership space. While the aim of this study was to understand middle leadership in Australian schools, including the diversity between various states and jurisdictions, further research of this kind across different countries would enhance our understandings of this space as it unfolds differently internationally.

References

AITSL (Australian Institute for Teaching and School Leadership) 2011. Australian Professional Standards for Teaching. https://www.aitsl.edu.au/docs/default-source/teachdocuments/australian-professional-standards-for-teachers.pdf

AITSL (Australian Institute for Teaching and School Leadership). 2014. Australian Professional Standard for Principals and the Leadership Profiles. https://www.aitsl.edu.au/docs/defaultsource/default-document-library/australian-professional-standard-for-principals-and-theleadership-profiles652c8891b1e86477b58fff00006709da.pdf?sfvrsn=11c4ec3c_0

AITSL (Australian Institute for Teaching and School Leadership). 2017. Are you a teacher that also leads? https://www.aitsl.edu.au/lead-develop/develop-yourself-as-a-leader/learn-frompractising-leaders/develop-leadership-using-both-standards

AITSL (Australian Institute for Teaching and School Leadership). 2017. Guide to the Certification of Highly Accomplished and Lead Teachers in Australia. https://www.aitsl.edu.au/docs/default-source/default-document-library/guide-tocert_online.pdf?sfvrsn $=95 \mathrm{e} 9 \mathrm{ec} 3 \mathrm{c} \_0$

AITSL (Australian Institute for Teaching and School Leadership). 2018. Leading for Impact. Australian guidelines for school leadership development. https://www.aitsl.edu.au/docs/defaultsource/national-policy-framework/leading-for-imapct-australian-guidelines-for-schoolleadership-development.pdf?sfvrsn=b67fff3c 4 
Bassett, M. 2016. 'The role of middle leaders in New Zealand secondary schools: Expectations and challenges.” Waikato Journal of Education 21(1): 97-108.

Bastow. 2019. CREATE: Middle Leader. Accessed June 242019.

https:/www.bastow.vic.edu.au/professional-learning/create-middle-leaders

Bourke, T,. M, Ryan,. and J, Lidstone. 2013. 'Reflexive professionalism: Reclaiming the voice of authority in shaping the discourse of educational policy.' Asia-Pacific Journal of Teacher Education 4 (4)1: 398-413.

Bowen, G. 2009. 'Document analysis as a qualitative research method.' Qualitative Research Journal 9(2): 27-40.

Boylan, M. 2018. 'Enabling adaptive system leadership: Teachers leading professional development.' Educational Management Administration \& Leadership 46(1): 86-106.

Brisbane Catholic Education. 2019. 'Working with Brisbane Catholic Education: Middle Leaders - Middle leadership positions in BCE secondary colleges'. Accessed on 24 June, 2019 http://www.bne.catholic.edu.au/bce-employment/about-senior\%20leadership/Pages/Middle$\underline{\text { Leaders.aspx }}$

Connell, R. 2009. 'Good teachers on dangerous ground: Towards a new view of teacher quality and professionalism.' Critical Studies in Education, 50(3): 213-229.

Cosenza, M. 2015. 'Defining teacher leadership: Affirming the teacher leader model standards'. Issues in Teacher Education, 24 (2): 79-99.

Davies, B. 2009. The Essentials of School Leadership, 2nd ed. London: Sage.

Day, C. 2017. Teachers Worlds and Work: Understanding Complexity, Building Quality. London: Routledge.

Day, Christopher, Qing Gu,. and Pam Sammons. 2016. 'The Impact of Leadership on Student Outcomes: How Successful School Leaders Use Transformational and Instructional Strategies to Make a Difference.' Educational Administration Quarterly, 52(2): 221-258. 
Day, C., and C. Grice. 2019. Investigating the influence and impact of Leading from the Middle: A School-based Strategy for Middle Leaders in Schools, http://hdl.handle.net/2123/19972

Diem, S., and M. Young. 2015. 'Considering critical turns in research on educational leadership and policy.' International Journal of Educational Management, 29(7): 838-850.

De Nobile, J. 2017. 'Towards a theoretical model of middle leadership in schools.' School Leadership \& Management, 38(4): 395-416.

De Nobile, J. and Boffa, S. 2014. 'The changing role of the primary coordinator in Catholic schools.' Independent Education, 44(2): 26-28.

Dinham, S. 2016. Leading Learning and Teaching. Camberwell: ACER Press.

Drysdale, L., D. Gurr, and H. Goode. 2016. 'Dare to Make a Difference: Successful Principals Who Explore the Potential of Their Role.' International Studies in Educational Administration 44 (3): 37-53.

Eaude, T. 2014. 'What makes primary class teachers special? Exploring the features of expertise in the primary classroom.' Teachers and Teaching: Theory and Practice 20(1): 4-18.

Edwards-Groves, C., P. Grootenboer, P., I. Hardy, and K. Rönnerman. 2019. 'Driving change from 'the middle': middle leading for site based educational development.' School Leadership \& Management 39(3-4): 315-333

Edwards-Groves, C., P. Grootenboer, and K Ronnerman. 2016. 'Facilitating a culture of relational trust in school-based action research: Recognising the role of middle leaders.' Educational Action Research 24(3): 369-386

Fair Work Commission Australia. 2018. NSW and ACT Catholic Schools Enterprise Agreement 2017. Sydney: Commonwealth Government Printer.

Fairman, J, and S. Mackenzie. 2015. 'How teacher leaders influence others and understand their leadership.' International Journal of Leadership in Education 18(1): 61-87. 
Fitzgerald, T. 2012. 'Documents and Documentary Analysis.' In Research Methods in Educational Leadership and Management, edited by A. R. J. Briggs, M. Coleman, and M. Morrison, 3rd ed., 296-308. London: Sage.

Fitzgerald, T. 2009. 'The tyranny of bureaucracy: Continuing challenges of leading and managing from the middle.' Educational Management, Administration and Leadership 37(1): $51-65$.

Forde, C., G. Hamilton., M. Ní Bhróithe., M. Nihill, and A Mai Rooney. 2019. 'Evolving policy paradigms of middle leadership in Scottish and Irish education: implications for middle leadership professional development.' School Leadership \& Management 39(3-4): 297-314.

Fransson, G, and S. McMahan. 2013. 'Exploring research on mentoring policies in education.' International Journal of Mentoring and Coaching in Education. 2(3): 218-232.

Fullan, M. 1993. Change Forces: Probing the Depths of Educational Reform. London, England: Falmer Press

Glover, D., D. Gleeson., G. Gough., and M Johnson. 1998. 'The Meaning of Management: The Development Needs of Middle Managers in Secondary Schools.' Educational Management and Administration 26 (3): 279-292.

Grice, C. 2018. 'Leading pedagogical reform.' International Journal of Leadership in Education, 22(3): 354-369

Grice, C. 2019. Distributed pedagogical leadership for the implementation of mandated curriculum change. Leading and Managing, 25(1), 56-71.

Gurr, D, and L. Drysdale. 2012. 'Tensions and Dilemmas in Leading Australia's Schools.' School Leadership \& Management 32: 403-420.

Grootenboer, P., C. Edwards-Groves, and K. Ronnerman. 2015. 'Leading Practice Development: Voices from the Middle.' Professional Development in Education 41: 508-526.

Grootenboer, P. 2018. The Practices of School Middle Leadership: Leading Professional Learning. Singapore: Springer. 
Hammersley-Fletcher, L., and M. Strain. 2011. 'Power, Agency and Middle Leadership in English Primary Schools.' British Educational Research Journal 37: 871-884.

Hargreaves, A., D. Shirley., S. Wangia., C. Bacon, and M. D'Angelo. 2018. Executive Summary: Leading from the Middle: Spreading Learning, Well-being, and Identity Across Ontario. Council of Ontario Directors of Education Report. Code Consortium, Leadership and Innovation.http://ccsli.ca/downloads/2018_Leading_From_the_Middle_Summary_Final-EN.pdf

Harris, A. and M. Jones. 2017. 'Middle leaders matter: reflections, recognition, and renaissance.' School Leadership \& Management. 37 (3): 213-216.

Hodder, I. 2000. The interpretation of documents and material culture. In Handbook of qualitative research, 2 nd ed., edited by N.K. Denzin and Y.S. Lincoln, 703-15. London: Sage.

Irvine, P., and M. Brundrett. 2016. 'Middle Leadership and Its Challenges: A Case Study in the Secondary Independent Sector.' Management in Education 30 (2): 86-92.

Labuschagne, A. 2003. Qualitative research: Airy fairy or fundamental? The Qualitative Report, 8(1), Article 7. http://www.nova.edu/ssss/QR/QR8-1/labuschagne.html.

Lambert, P., W. Marks., V. Elliott, and N. Johnston-Anderson. 2016. 'Generational change in Australian school leadership: Collision path or smooth baton change?' Journal of Educational Administration, 54(2): 114-134.

Lárusdóttir, S. H, and E. O’Connor .2017. 'Distributed leadership and middle leadership practice in schools: a disconnect?' Irish Educational Studies, 36 (4): 423-438.

Leithwood, K. 2016. 'Department-head leadership for school improvement.' Leadership and Policy in Schools 15(2): 117-140.

Leithwood, K., B. Mascall., T. Strauss., R. Sacks., N. Memon and A. Yashkina. 2006. 'Distributing leadership to make schools smarter: taking the ego out of the system.' Leadership and Policy in Schools, 6(1), 37-67. 
Lipscombe, K., S. Tindall-Ford, and P. Grootenboer. 2019. 'Middle leading and influence in two Australian Schools'. Advance online publication. doi.org/10.1177/1741143219880324

Lipscombe, K., S. Tindall-Ford, and M. Kirk. 2019. 'Leading a Top Down Directive From the Bottom Up: A School and University Partnership.' Leading \& Managing 25 (1): 29-43.

Lumby, J. 2019. 'Distributed Leadership and bureaucracy.' Educational Management Administration \& Leadership 47(1): 5-19.

Marks, W and N. McCulla. 2016. 'Halfway to anywhere?' In Trust and Verify: The Real Keys to School Improvement edited by D. Fink (pp. 46-73). London: UCL IOE Press.

McGrath-Champ, S., R. Wilson., M Stacey, and S Fitzgerald. 2018. 'Understanding Work in Schools: The Foundation for Teaching and Learning.'

https://news.nswtf.org.au/application/files/7315/3110/0204/Understanding-Work-In-Schools.pdf

Mulford, B. and H Silins. 2003. 'Leadership for Organisational Learning and Improved Student Outcomes-What Do We Know?' Cambridge Journal of Education 33(2): 175-195.

Muijs, D and A. Harris. 2007. 'Teacher leadership in (in)action: Three case studies of contrasting schools.' Educational Management Administration \& Leadership 35(1): 111-134.

Nesli (2019). Catholic Schools Middle Leadership Program. Accessed November 192019 https:/www.nesli.org/catholicmiddleleadersprogram.html

New South Wales Department of Education. 2017. Principal Workload and time use study. https:/education.nsw.gov.au/media/schools-operation/Principal-workload-and-time-use-studyNov-2017.pdf

New South Wales Department of Education. 2018. Annual Report 2018. Sydney: N.S.W. Department of Education.

NSW AIS (New South Wales Association of Independent Schools). 2019. Middle Leaders. Accessed on May 192019 https://www.aisnsw.edu.au/school-leaders/leadership/leadershipcentre/we-come-to-you/leading-from-the-middle 
QeLi (Queensland Educational Leadership Institute). 2019. Leadership for Middle Leaders Program. Accessed July 212019 https://qeli.qld.edu.au/leadership-for-middle-leaders-program/

Queensland Department of Education. (2019). Working with us: Example role descriptions. Retrieved on 24 June, 2019 from https://qed.qld.gov.au/working-with-us/currentvacancies/example-role-descriptions

Perryman, J. 2012. 'Discourse Analysis.' In Research Methods in Educational Leadership and Management, edited by A. R. Briggs, M. Morrison, and M. Coleman, 309-321. London: Sage.

Riley, P. 2014. 'Principals' psychological health: It's not just lonely at the top, it's dangerous.' InPsych, 36(6), Retrieved on 20 June, 2019 from https://www.psychology.org.au/inpsych/2014/december/riley

Robinson, V. M. J., Hohepa, M., \& Lloyd, C. (2009). School leadership and student outcomes: Identifying what works and why, Best Evidence Synthesis. Wellington: Ministry of Education.

Scott, J. 1990. A matter of record, Documentary Sources in Social Research. Cambridge: Policy.

Shore, C and S. Wright. 2011. 'Conceptualising policy: Technologies of governance and the politics of visibility'. In Policy Worlds: Anthropology and Analysis of Contemporary Power edited by C Shore, S Wright, and D Pero. New York: Berghahn, 1-26.

Smith, G. 2002. 'Place-Based Education: Learning to Be Where We are. Phi Delta Kappan 83(8): 584-594

Spillane, J.P. 2006. Distributed Leadership. San Fransisco, CA: Jossey-Bass

Sydney Catholic Schools and NSWIEU. (2018). Framework for Workplace Practices in Primary Schools conducted by Sydney Catholic Schools 2018-2019. Retrieved on 20 June, 2019 from https://sydcatholicschools.nsw.edu.au/wp-content/uploads/2018/03/Sydney-Catholic-SchoolsPrimary-Work-Practices-Agreement-2018-2019.pdf

The Education Gazette. 1961. Equality of opportunity for men and women teachers. The Education Gazette, 55(8): 337-341. 
Victoria Department of Education and Training. (2017). Roles and Responsibilities: Teaching Service. Retrieved on 20 June, 2019 from

https://www.education.vic.gov.au/hrweb/Documents/Roles_and_responsibilities-TS.pdf

Western Australia Department of Education. (2019). Middle leader's professional learning. Retrieved on 27 June, 2019 from det.wa.edu.au/professionallearning/detcms/navigation/middleleaders/

Wilkinson, J. and S. Kemmis. 2015. Practice theory: viewing leadership as leading. Educational Philosophy and Theory 47(4), 342-358.

Wilkinson, J. 2017. Reclaiming Education in Educational Leadership. In P. Grootenboer, C. Edwards-Groves, \& S. Choy (Eds.) Practice theory perspectives on pedagogy and education. (pp231-241) Singapore: Springer

Young, M. D., and S. Diem. 2017. 'Introduction: Critical Approaches to Policy Analysis.' In

Critical Approaches to Education Policy Analysis, edited by M. D. Young, and S. Diem, 1-18. Switzerland: Springer International Publishing.

Youngs, H. 2014. 'Moving beyond distributed leadership to distributed forms: A contextual and socio-cultural analysis of two New Zealand secondary schools'. Leading \& Managing 20(2), 89104. 